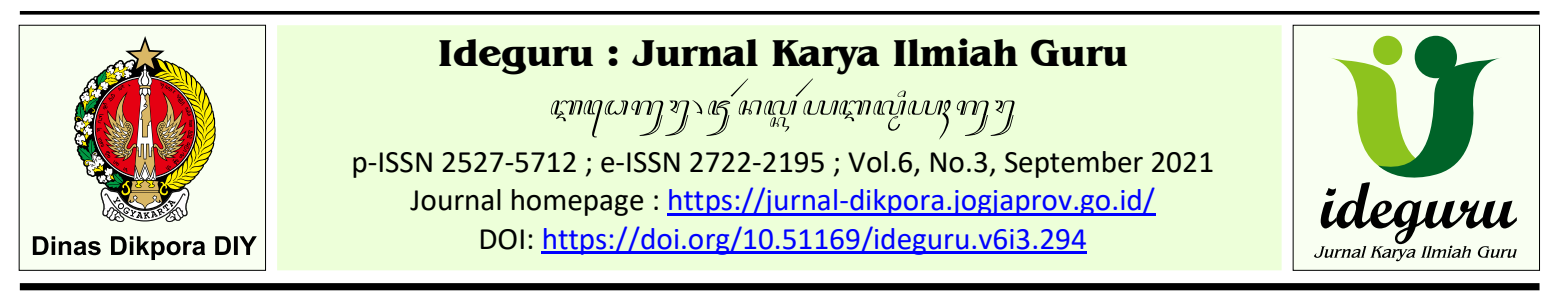

Artikel Penelitian - Naskah dikirim: 06/06/2021 - Selesai revisi: 10/08/2021 - Disetujui: 13/08/2021 - Diterbitkan: 01/09/2021

\title{
Peningkatan Keterampilan Berpikir Tingkat Tinggi dalam Pembelajaran Teks Information Report melalui Formative Assessment with Reasoning Worksheet
}

\author{
Ponikem \\ SMP Negeri 1 Wonosari \\ ponikem.new@gmail.com
}

\begin{abstract}
Abstrak: Penelitian ini bertujuan meningkatkan keterampilan berpikir tingkat tinggi (KBTT) peserta didik dalam pembelajaran teks information report melalui Formative Assessment with Reasoning (FAR) Worksheet di kelas IXE SMP Negeri 1 Wonosari pada semester 2 tahun pelajaran 2019/2020. Penelitian ini terdiri dari 2 siklus. Siklus 1 terdiri dari 3 pertemuan dan Siklus 2 terdiri dari 2 pertemuan. Tahapan penelitian meliputi merencanakan, melaksanakan dan mengamati, dan merefleksi. Data penelitian ini diambil melalui tes, angket dan pengamatan proses pembelajaran. Hasil tes dan angket diolah, dicari reratanya dan kemudian dibandingkan dengan indikator keberhasilan. Data hasil pengamatan diolah dengan melakukan pencacahan terhadap hasil pengamatan kegiatan guru dan peserta didik. Hasil pencacahan dikonversi dalam kategori "Sangat Rendah", "Rendah", "Tinggi" dan "Sangat Tinggi". Hasil penelitian adalah meningkatnya KBTT peserta didik yang ditunjukkan dengan kenaikan rerata hasil tes dan angket. Perbandingan rerata nilai tes awal, tes akhir Siklus 1, dan tes akhir Siklus 2 adalah 51,7:46,4:68,5. Indikator keberhasilan berdasarkan hasil tes terpenuhi dengan diperolehnya kenaikan sebesar 22,1. Perbandingan rerata persentase peserta didik menjawab "Yakin" dan "Sangat Yakin" pada pernyataan 4, 5, dan 6 yang merupakan konfirmasi kemampuan peserta didik dalam mengerjakan soal tipe C4, C5, dan C6 yang mewakili keterampilan berpikir tingkat tinggi level analyzing, evaluating, dan creating pada Siklus 1 dan Siklus 2 adalah 23,61\% dan 30,43\%. Indikator keberhasilan berdasarkan hasil angket terpenuhi dengan diperolehnya kenaikan sebesar 6,82\%. Kualitas proses pembelajaran meningkat menjadi "HIGH" berdasarkan hasil pengamatan.
\end{abstract}

Kata kunci: keterampilan berpikir tingkat tinggi, teks information report, formative assessment with reasoning.

\section{Improving Higher Order Thinking Skills in Information Report Text Learning through Formative Assessment with Reasoning Worksheet}

\begin{abstract}
This study aimed at improving students' higher order thinking skills (HOTS) in learning information report texts through Formative Assessment with Reasoning (FAR) Worksheets in class IXE SMP Negeri 1 Wonosari in semester 2 of the 2019/2020 academic year. This research consisted of 2 cycles. Cycle 1 consisted of 3 meetings and Cycle 2 consisted of 2 meetings. The stages of research included planning, implementing and observing, and reflecting. The research data were taken through tests, questionnaires and observations of the learning process. The test results and questionnaires were processed, averaged and then compared with indicators of success. Observational data were processed by enumeration of the results of observations of teacher and student activities. The results of the enumeration were converted into "Very Low", "Low", "High" and "Very High" categories. The results of the study were the increase in the HOTS of students as indicated by the increase in the average results of tests and questionnaires. The comparison of the mean scores of the initial test, the final test of Cycle 1, and the final test of Cycle 2 was 51.7:46.4:68.5. Indicators of success based on test results were met by obtaining an increase of 22.1. Comparison of the average percentage of students answering "Confident" and "Very Confident" on statements 4, 5, and 6 which were confirmations of students' abilities in working on questions of types C4, C5, and C6 which represented higher-order thinking skills at the level of analyzing, evaluating, and creating in Cycle 1 and Cycle 2 was $23.61 \%$ and 30,43\%. The indicator of success based on the results of the questionnaire was met with an increase of $6.82 \%$. The quality of the learning process increased to "HIGH" based on the observations.
\end{abstract}

Keywords: higher order thinking skills, information report text, formative assessment with reasoning. 


\section{Pendahuluan}

Menguasai keterampilan berpikir tingkat tinggi (KBTT) merupakan salah satu syarat untuk survive di abad ke-21. Fenomena bahwa dunia dikatakan volatile, uncertain, complex, dan ambiguous sebagaimana dinyatakan oleh Biech (2015) harus dihadapi dengan keterampilan abad ke-21 yang meliputi communication, collaboration, creativity, critical thinking and problem solving. Kepemilikan keterampilan tersebut memerlukan proses dan melibatkan pembelajaran di kelas yang inovatif. Dalam pembelajaran nyata di SMP Negeri 1 Wonosari, penggunaan Worksheet atau Lembar Kerja Peserta Didik (LKPD) masih berupa LKPD yang memuat sejumlah pertanyaan yang sebagian besar hanya menuntut level berpikir remembering, understanding dan applying. LKPD tersebut sudah saatnya didesain ulang sedemikian rupa sehingga dapat memfasilitasi pengembangan level keterampilan berpikir yang lebih tinggi, yakni analyzing, evaluating, bahkan pada level tertinggi, yakni creating. Terpilihnya kelas IXE sebagai subjek penelitian didasarkan pada 2 alasan. Pertama, berdasarkan penilaian semester 1 tahun pelajaran 2019/2020 kelas ini memiliki rerata terendah. Kedua, peserta didik IXE cenderung pendiam dan penurut ketika diberi tugas, meskipun hasilnya kurang optimal.

Salah satu KD Bahasa Inggris sebagaimana tercantum dalam Permendikbud nomor 37 tahun 2018 adalah KD nomor 3.9, yang berbunyi "Membandingkan fungsi sosial, struktur teks, dan unsur kebahasaan beberapa teks information report lisan dan tulis dengan memberi dan meminta informasi terkait mata pelajaran lain di Kelas IX, pendek dan sederhana, sesuai dengan konteks penggunaannya". Anderson \& Krathwohl (2001) mengategorikan "membandingkan" ke dalam dimensi proses kognitif level 4 (C4), yakni analyze. Level kognitif analyze, lebih lanjut dijelaskan oleh Anderson \& Krathwohl berupa kemampuan menguraikan material ke dalam bagian-bagian dan menentukan keterkaitan baik antar bagian maupun keseluruhan struktur dan tujuan. Level kognitif analyze ini terdiri dari tiga (3) kategori, yakni differentiating, organizing, dan attributing.

FAR Worksheet dalam artikel ini merupakan LKPD yang butir-butir task atau soal latihannya disusun secara gradatif sesuai urutan level keterampilan berpikir dari C1 sampai dengan C6. Dalam proses pembelajaran peserta didik mengerjakan LKPD tersebut yakni dengan cara menjawab soal-soal yang menuntut penalaran untuk kemudian diberikan feedback oleh guru. Feedback tersebut berfungsi sebagai formative assessment. Penggunaan Formative Assessment with Reasoning (FAR) Worksheet diharapkan dapat memfasilitasi peserta didik meningkatkan KBTT mereka.

KBTT menurut Brookhart (2015) dikategorikan ke dalam tiga hal, yakni KBTT sebagai transfer, critical thinking, dan problem solving. KBTT sebagai hasil pembelajaran dimaknai sebagai being able to think. Pengertian being able to think dalam kategori transfer menitikberatkan pada kemampuan peserta didik dalam mengaplikasikan pengetahuan dan keterampilan yang dikembangkan dalam pembelajaran ke dalam konteks baru. Being able to think dalam kategori critical thinking dimaknai sebagai kemampuan mengaplikasikan penilaian bijak atau menghasilkan kritik yang beralasan. Kategori ketiga, problem solving, mendefinisikan being able to think sebagai kemampuan peserta didik untuk memecahkan masalah dan bekerja secara kreatif. Dalam praktik pembelajaran, guru memfasilitasi peserta didik untuk mampu memecahkan masalah baik terkait hal-hal akademik maupun kehidupan nyata sekaligus menciptakan sesuatu sebagai solusi atas masalah tersebut.

Teks information report didefinisikan oleh Anderson \& Anderson (1997) sebagai sebuah teks yang menyajikan informasi tentang suatu subjek yang memuat fakta-fakta tentang subjek tertentu, deskripsi dan informasi terkait bagian-bagian, tingkah laku, dan kualitas. Teks information report dapat berupa buku teks pelajaran, kuliah, tugas penelitian dan artikel referensi. Struktur teks information report terdiri dari: 1) general opening, 2) a series of paragrafs about the subject, dan 3) a conclusion.

Formative assessment dimaknai sebagai assessment for learning dan assessment as learning, oleh Lorna Earl (2003) dalam Tomlinson \& Moon (2013). Dalam assessment for learning guru membangun dan menggunakan pengetahuan personalnya untuk mengidentifikasi keberagaman kebutuhan peserta didik untuk layanan pembelajarannya. Dalam assessment as learning peserta didik merupakan penghubung antara assessment dan learning yang memungkinkan peserta didik aktif terlibat dalam penilaian sehingga mampu mendefinisikan secara jelas tingkat ketercapaian tujuan pembelajaran serta memanfaatkan feedback untuk memperbaiki proses dan capaian belajarnya.

Reasoning menurut Butterworth \& Thwaites (2013) merupakan proses mengembangkan halhal yang sudah diketahui menjadi pengetahuan dan pemahaman baru secara rasional. Dalam 
pembelajaran di kelas, keterampilan reasoning dapat dikembangkan dengan memfasilitasi peserta didik untuk mengungkapkan isi pikirannya dalam menjawab pertanyaan "why". Jawaban atas pertanyaan "why" tersebut dikategorikan "sound" atau "logic" menurut Brookhart (2010) apabila dalam menjawab peserta didik melibatkan proses berpikir analitis, evaluative, kritis, relevan dengan argumen, dan konsisten.

Berdasarkan latar belakang masalah sebagaimana diuraikan di atas, rumusan masalah dalam penelitian ini adalah bagaimana meningkatkan KBTT peserta didik dalam pembelajaran teks information report pada kelas IXE di SMP Negeri 1 Wonosari pada semester 2 tahun pelajaran 2019/2020 dengan FAR Worksheet.

Tujuan penelitian ini adalah meningkatkan KBTT peserta didik dalam pembelajaran teks information report pada kelas IXE di SMP Negeri 1 Wonosari pada semester 2 tahun pelajaran 2019/2020 melalui FAR Worksheet.

Hasil penelitian ini diharapkan bermanfaat bagi pendidik sebagai salah satu alternatif solusi dalam merancang LKPD; bagi peserta didik dapat memberi pengalaman belajar dalam mengembangkan KBTT; bagi sekolah penelitian ini dapat meningkatkan kualitas pembelajaran, dan bagi guru pendidik peneliti, penelitian ini dapat menjadi salah satu referensi atau inspirasi untuk mengembangkan penelitian lebih lanjut.

\section{Metode Penelitian}

Penelitian ini adalah penelitian tindakan kelas karena bertujuan memberikan tindakan untuk meningkatkan KBTT peserta didik, dalam pembelajaran teks information report di kelas IXE pada semester 2 tahun pelajaran 2019/2020 melalui penggunaan FAR Worksheet. Subjek penelitian ini adalah 24 peserta didik yang terdiri dari 7 laki-laki dan 17 perempuan. Dilaksanaan secara kolaboratif dengan teman sejawat yang berperan sebagai observer dan mitra diskusi, penelitian ini berlangsung dalam kurun waktu 3 (tiga) bulan yakni dari bulan Januari sampai dengan Maret 2020 di SMP Negeri 1 Wonosari.

Mengadaptasi model siklus Kemmis dan McTaggart (1988) dan Kemmis et.al (2014) seperti terlihat pada gambar 1 , penelitian ini dilaksanakan sebanyak 2 (dua) siklus, siklus 1 terdiri dari 3 pertemuan dan siklus 2 terdiri dari 2 pertemuan sebagai berikut.

\section{Tahapan Tindakan Siklus 1}

Pada tahap perencanaan (planning), pendidik menyiapkan RPP untuk KD 3.9 dengan materi teks information report, LKPD (FAR
Worksheet) dan instrumen yang terdiri dari Tes Awal dan Tes Akhir Siklus 1, angket Siklus 1 dan lembar pengamatan kegiatan siswa dan guru.

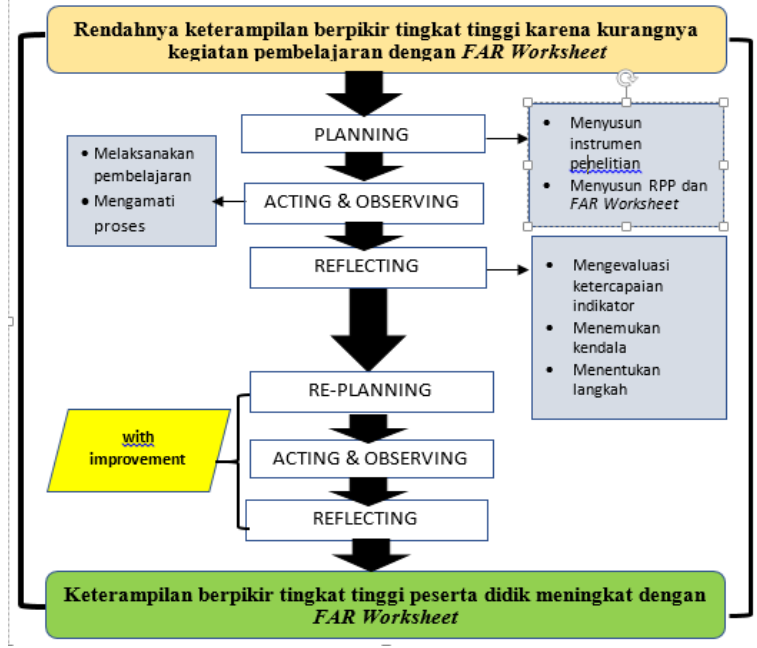

Gambar 1. Desain Penelitian Tindakan Kelas

Tahap tindakan dan pengamatan (acting and observing) pertemuan 1 dilaksanakan Jum'at, 10 Januari 2020. Sehari sebelumnya, Kamis, 9 Januari 2020 peserta didik mengerjakan soal tes awal dan mengisi angket Pra Siklus yang bertujuan memperoleh gambaran awal kondisi peserta didik. Langkah-langkah pembelajaran inti berupa Pre-Whilst-Post Reading mengadaptasi teknik pembelajaran membaca yang dikemukakan oleh Brown (2001), yakni prereading, during-reading, and after-reading phases, yang popular disebut Three-Phase Technique. Materi teks bertemakan fenomena alam tentang "Rocks" yang langkah-langkah pembelajarannya sudah tercantum dalam FAR Worksheet. Pada fase Pre-reading, peserta didik dikenalkan dengan istilah-istilah teknis tentang batuan dengan cara melengkapi kalimat rumpang dengan kata-kata yang tersedia. Kegiatan selanjutnya, Whilstreading, peserta didik menjawab pertanyaan yang disusun secara gradatif dari tipe C1 sampai dengan C5 secara berpasangan atau dalam kelompok kecil dengan peserta didik lain yang berdekatan tempat duduknya. Pada fase Postreading, peserta didik diminta membuat outline atau ringkasan dari teks yang dibaca. Outline atau ringkasan ini dipakai untuk panduan presentasi sebagai perwujudan dari level berpikir C6. Sampai waktu habis peserta didik baru dapat menyelesaikan $30-40 \%$ pertanyaan. Tipe pertanyaan yang berhasil dijawab yakni tipe C1 dan C2. Pertanyaan yang belum terjawab dikerjakan di rumah dan diperiksa pada pertemuan berikutnya.

Pertemuan 2 dilaksanakan Kamis, 16 Januari 2020 jam pertama dan kedua (80 menit) dengan kegiatan pengecekan hasil penyelesaian 
FAR Worksheet, penyampaian feedback dan perbaikan jawaban sesuai feedback. Hasil pengecekan menunjukkan 100\% peserta didik berhasil menjawab pertanyaan tipe C1 dan C2.
Jawaban pertanyaan tipe C3, C4, dan C5 masih harus diperbaiki berdasarkan feedback yang diberikan. Tabel 1 berikut menyajikan contoh jawaban peserta didik berikut feedbacknya.

Tabel 1. Contoh Jawaban Peserta Didik dan Feedback Pendidik

\begin{tabular}{|c|c|c|}
\hline Pertanyaan (Tipe) & Jawaban Peserta Didik & Feedback Guru \\
\hline $\begin{array}{l}\text { Visualize how } \\
\text { "Sandwich Rocks" } \\
\text { and "Cooked } \\
\text { Rocks" form. (C4) }\end{array}$ & $\begin{array}{l}\text { Peserta didik diminta untuk menuliskan } \\
\text { jawabannya pada Task } 2 \text { (Post Reading } \\
\text { Activity). }\end{array}$ & $\begin{array}{l}\text { Guru menekankan kepada peserta } \\
\text { didik untuk menginvestigasi "bahan- } \\
\text { proses-hasil" untuk diskemakan } \\
\text { dalam bentuk gambar. }\end{array}$ \\
\hline $\begin{array}{l}\text { How does the } \\
\text { author organize } \\
\text { the information or } \\
\text { facts about rocks? } \\
\text { (C5) }\end{array}$ & $\begin{array}{l}\text { Semua peserta didik kesulitan menjawab } \\
\text { pertanyaan ini karena guru belum } \\
\text { memberikan penjelasan tentang struktur } \\
\text { generic atau alur berpikir penulis dalam } \\
\text { menyusun teks information report. }\end{array}$ & $\begin{array}{l}\text { Guru menjelaskan feedback nya di } \\
\text { papan tulis yang merupakan } \\
\text { penjelasan induktif dari struktur } \\
\text { generic teks information report. }\end{array}$ \\
\hline
\end{tabular}

Pertemuan 3 dilaksanakan Jum'at, 20 Januari 2021 pada jam ketiga dan keempat (80 menit). Kegiatan pembelajaran meliputi menyusun kembali teks berdasarkan outline dan membaca nyaring teks yang sudah dihasilkan. Kedua kegiatan ini merupakan Post-reading. Pengamatan kegiatan pembelajaran baik terhadap peserta didik maupun pendidik dilaksanakan selama pembelajaran pada ketiga pertemuan tersebut. Pengamatan dilakukan oleh peserta didik dan guru menggunakan lembar pengamatan. Sebelum memasuki tahapan reflecting, peserta didik mengerjakan Tes Akhir Siklus 1 dan mengisi angket Akhir Siklus 1.

Tahapan terakhir siklus 1 adalah merefleksi (reflecting). Tahapan ini dilakukan dengan mengevaluasi hasil tindakan pada siklus 1 menggunakan data dari hasil tes akhir, angket, dan hasil pengamatan kegiatan guru dan peserta didik. Evaluasi dilakukan bersama kolaborator, peserta didik dan guru. Hasil evaluasi dijadikan dasar menyusun rencana pembelajaran siklus 2 .

\section{Tahapan Tindakan Siklus 2}

Pada tahap perencanaan (planning), pendidik menyiapkan RPP untuk KD 3.9 dengan materi teks information report, LKPD (FAR Worksheet) dan instrumen, yang terdiri dari Tes Akhir Siklus 2, angket Siklus 2 dan lembar pengamatan kegiatan siswa dan guru.
Tahap tindakan dan pengamatan (acting and observing) pertemuan 1 dilaksanakan Jum'at, 24 Januari 2020. Pada siklus 2 ini materi teks bertemakan fenomena sosial tentang "Banks" yang langkah-langkah pembelajarannya sudah tercantum dalam FAR Worksheet. Pada fase Prereading, peserta didik dikenalkan dengan istilahistilah teknis tentang perbankan dengan cara mencari padanan dalam Bahasa Indonesia kata atau istilah perbankan. Kegiatan selanjutnya, Whilst-reading, peserta didik menjawab pertanyaan yang disusun secara gradatif dari tipe C1 sampai dengan C5 dalam kelompok kecil yang dibentuk oleh guru beranggotakan 3 orang. Hal ini dilakukan berdasarkan hasil refleksi akhir siklus 1. Pada akhir pertemuan, peserta didik mengumpulkan hasil kerjanya untuk diberi feedback. Penyampaian feedback dilaksanakan pada pertemuan 2 .

Pertemuan 2 dilaksanakan pada hari Kamis, 30 Januari 2021 dengan agenda penyampaian feedback dan pelaksanaan fase Post-reading berupa menyusun kembali teks tentang "Banks" berdasakan outline atau ringkasan yang sudah disusun sebelumnya. Penyampaian feedback lebih banyak tertuju pada jawaban pertanyaan tipe C3, C4, C5, dan C6. Tabel 2 berikut menyajikan contoh jawaban peserta didik berikut feedbacknya.

Tabel 2. Contoh Pertanyaan beserta Jawaban dan Feedbacknya

\begin{tabular}{|c|c|c|}
\hline $\begin{array}{l}\text { Pertanyaan } \\
\text { (Tipe) }\end{array}$ & Jawaban Peserta Didik & Feedback Guru \\
\hline $\begin{array}{l}\text { Nomor } 3 . \\
\text { How does a } \\
\text { holder of } \\
\text { bank } \\
\text { account use } \\
\text { check? (C3) }\end{array}$ & $\begin{array}{l}\text { The holder can use check to pay bill } \\
\text { by paying a telephone bill with a } \\
\text { check and than the telephone } \\
\text { company sends the check to its own } \\
\text { bank and the money owe goes from } \\
\text { the bank account to the telephone } \\
\text { company's bank account. } \\
\text { (E/09) }\end{array}$ & $\begin{array}{l}\text { Jawaban ini diberi skor } 2 \text { yang harusnya } 3 \text {. Jawaban } \\
\text { ini belum menunjukkan peserta didik menangkap } \\
\text { mekanisme penggunaan cek. Jawaban ini sekedar } \\
\text { menyalin contoh kasus pembayaran tagihan telepon } \\
\text { dengan cek. Jawaban yang disarankan: } \\
\text { "A check is a promise to pay. It is used as an } \\
\text { instruction to transfer money from the bank account } \\
\text { holder to the company's bank account." }\end{array}$ \\
\hline
\end{tabular}




\begin{tabular}{|c|c|c|}
\hline $\begin{array}{l}\text { Pertanyaan } \\
\text { (Tipe) }\end{array}$ & Jawaban Peserta Didik & Feedback Guru \\
\hline & $\begin{array}{l}\text { People put money in a bank and } \\
\text { the bank give them a bank account. } \\
\text { Then the bank give you check and } \\
\text { then you can pay bills with the } \\
\text { check. Check can transfer money } \\
\text { form own bank account to other } \\
\text { bank account. } \\
\text { (E/05) }\end{array}$ & $\begin{array}{l}\text { Jawaban ini diberi skor } 3 \text {. Peserta didik sudah } \\
\text { mampu mengkonstruksi kalimat berdasarkan contoh } \\
\text { kasus yang ada di teks. Meskipun sudah diberi skor } \\
\text { optimal, guru masih memberi feedback sebagai } \\
\text { alternatif jawaban yang memperkuat } \\
\text { pemahamannya. } \\
\text { Feedback tersebut berbunyi: } \\
\text { "A check is a promise to pay. The check is sent to } \\
\text { company's bank account to which our payment goes. } \\
\text { The amount of money stated on the check goes from } \\
\text { the holder of bank account to the companys bank } \\
\text { account." }\end{array}$ \\
\hline
\end{tabular}

Setelah penyampaian feedback, peserta didik diberi kesempatan memperbaiki jawabannya. Pada fase Post-reading peserta didik menyusun kembali teks berjudul "Banks" berdasarkan bagan atau skema atau outline yang sudah disusun. Pengamatan kegiatan pembelajaran baik terhadap peserta didik maupun guru dilaksanakan selama pembelajaran pada kedua pertemuan tersebut. Pengamatan dilakukan oleh peserta didik dan guru menggunakan lembar pengamatan. Sebelum memasuki tahapan reflecting, peserta didik mengerjakan Tes Akhir Siklus 2 dan mengisi Angket Siklus2.

Tahapan terakhir siklus 2 adalah merefleksi (reflecting). Tahapan ini dilakukan dengan mengevaluasi hasil tindakan pada siklus 2 menggunakan data dari hasil tes akhir, angket, dan hasil pengamatan kegiatan guru dan peserta didik. Evaluasi dilakukan bersama kolaborator, peserta didik dan guru. Hasil evaluasi berdasarkan data hasil tes akhir dan angket menunjukkan bahwa tindakan dalam penelitian ini telah berhasil meningkatkan KBTT sesuai indikator keberhasilan. Hal-hal yang masih menjadi kendala pada siklus 2 menjadi catatan penelitian berikutnya.

Data pada penelitian ini diperoleh dari tes (awal, akhir Siklus 1 dan akhir Siklus 2), angket pada akhir tiap siklus, pengamatan kegiatan guru dan peserta didik, catatan harian dan foto. Hasil tes, angket dan pengamatan menjadi data primer. Catatan harian dan foto menjadi data sekunder.

Instrumen penelitian berupa tes, angket dan pengamatan kegiatan pembelajaran disusun berdasarkan kisi-kisi yang dipaparkan dalam tabel 3. Butir soal dalam tes disusun berdasarkan indikator yang sama dengan indikator penyusunan LKPD. Butir soal tes disusun secara gradatif yang mencerminkan keterampilan berpikir dari level paling rendah (C1) sampai dengan level paling tinggi (C5) atau (C6). Hasil tes dihitung dengan cara memberi bobot setiap butir sesuai dengan tipe soal, yakni C1 diberi bobot $1, \mathrm{C} 2-2$, C3 -3 , dan seterusnya sampai C6. Pembobotan ini dibuat dengan mempertimbangkan level keterampilan berpikir yang diperlukan untuk menjawan setiap tipe soal. Skor akhir hasil tes dihitung dengan rumus skor perolehan dibagi skor maksimal dikalikan 100 .

Angket memuat sejumlah pernyataan yang berfungsi untuk mengkonfirmasi keyakinan peserta didik dalam menjawab butir soal dalam tes. Angket ini dirancang untuk mengukur tingkat keyakinan peserta didik akan kemampuannya menjawab pertanyaan dari tipe paling rendah $\mathrm{C} 1$ sampai paling tinggi C6. Angket ini diisi segera setelah peserta didik menyelesaikan tes. Setiap pernyataan dalam angket diikuti 5 pilihan (sangat tidak yakin, tidak yakin, ragu-ragu, yakin dan sangat yakin). Lembar pengamatan terdiri dari sejumlah butir kegiatan yang dilakukan guru dan peserta didik selama pembelajaran. Pengamat mengisi instrumen tersebut dengan cara memberi tanda pada kolom yang sesuai dengan kondisi yang diamati (sangat rendah, rendah, tinggi, sangat tinggi). Catatan harian berupa kesan pesan peserta didik disampaikan secara tertulis pada halaman di balik angket yang diisi pada setiap akhir siklus. Catatan tersebut dipindai, discreenshoot, dan disalintempel ke dokumen word. Foto diambil pada setiap pertemuan dan kemudian didokumentasikan dalam bentuk word.

Data penelitian yang dihasilkan dari tes diperoleh dengan mengoreksi jawaban peserta didik dan memberinya bobot pada setiap butir soal. Nilai akhir adalah hasil dari jumlah bobot seluruh butir soal yang diperoleh dibagi jumlah bobot maksimal dikalikan 100. Nilai rerata kelas diperoleh dengan menjumlah nilai seluruh peserta didik kemudian dibagi jumlah peserta didik. Hasil angket berupa persentase jumlah peserta didik yang menjawab untuk setiap kategori. Persentase ini dihitung dengan rumus: jumlah peserta didik untuk tiap kategori dibagi jumlah seluruh peserta didik dikalikan 100\%. 
Keberhasilan penelitian diukur berdasarkan indikator keberhasilan yang telah ditentukan. Hasil pengamatan diolah dengan mencacah dan mengategorikannya dalam 4 kategori (sangat rendah, rendah, tinggi, sangat tinggi).

Tabel 3. Kisi-kisi Tes

\begin{tabular}{|c|c|c|c|c|}
\hline \multirow{2}{*}{$\begin{array}{l}\text { Kompetensi } \\
\text { Dasar }\end{array}$} & \multirow[t]{2}{*}{ Materi } & \multicolumn{3}{|c|}{ Indikator Soal } \\
\hline & & Tes awal & $\begin{array}{l}\text { Tes akhir } \\
\text { Siklus } 1 \\
\end{array}$ & $\begin{array}{l}\text { Tes akhir } \\
\text { Siklus } 2\end{array}$ \\
\hline \multirow{6}{*}{$\begin{array}{l}\text { Membandin } \\
\text { gkan fungsi } \\
\text { sosial, } \\
\text { struktur } \\
\text { teks, dan } \\
\text { unsur } \\
\text { kebahasaan } \\
\text { beberapa } \\
\text { teks } \\
\text { information } \\
\text { report lisan } \\
\text { dan tulis } \\
\text { dengan } \\
\text { memberi } \\
\text { dan } \\
\text { meminta } \\
\text { informasi } \\
\text { terkait mata } \\
\text { pelajaran } \\
\text { lain di Kelas } \\
\text { IX, pendek } \\
\text { dan } \\
\text { sederhana, } \\
\text { sesuai } \\
\text { dengan } \\
\text { konteks } \\
\text { penggunaan } \\
\text { nya }\end{array}$} & \multirow{6}{*}{$\begin{array}{l}\text { Teks } \\
\text { inform } \\
\text { ation } \\
\text { report } \\
\text { dengan } \\
\text { tema } \\
\text { fenome } \\
\text { na } \\
\text { alam } \\
\text { dan } \\
\text { fenome } \\
\text { na } \\
\text { sosial }\end{array}$} & $\begin{array}{l}\text { Diberikan teks } \\
\text { information report } \\
\text { tentang fenomena } \\
\text { alam (batuan), peserta } \\
\text { didik dapat } \\
\text { mengidentifikasi } \\
\text { bagian struktur teks } \\
\text { berupa identifikasi } \\
\text { atau definisi dengan } \\
\text { benar. (C1) }\end{array}$ & $\begin{array}{l}\text { Diberikan teks } \\
\text { information report } \\
\text { tentang fenomena } \\
\text { alam (tanah), peserta } \\
\text { didik dapat } \\
\text { mengidentifikasi } \\
\text { bagian struktur teks } \\
\text { berupa identifikasi } \\
\text { atau definisi dengan } \\
\text { benar. (C1) }\end{array}$ & $\begin{array}{l}\text { Diberikan teks information } \\
\text { report tentang fenomena } \\
\text { sosial (uang), peserta didik } \\
\text { dapat mengidentifikasi } \\
\text { bagian struktur teks berupa } \\
\text { identifikasi atau definisi } \\
\text { dengan benar. (C1) }\end{array}$ \\
\hline & & $\begin{array}{l}\text { Diberikan teks } \\
\text { information report } \\
\text { tentang fenomena } \\
\text { alam (batuan), peserta } \\
\text { didik dapat } \\
\text { menjelaskan jenis-jenis } \\
\text { batuan dalam teks } \\
\text { dengan benar. (C2) }\end{array}$ & $\begin{array}{l}\text { Diberikan teks } \\
\text { information report } \\
\text { tentang fenomena } \\
\text { alam (tanah), peserta } \\
\text { didik dapat } \\
\text { menjelaskan jenis- } \\
\text { jenis batuan dalam } \\
\text { teks dengan benar. } \\
\text { (C2) }\end{array}$ & $\begin{array}{l}\text { Diberikan teks information } \\
\text { report tentang fenomena } \\
\text { sosial (uang), peserta didik } \\
\text { dapat menjelaskan cara } \\
\text { orang menilai atau } \\
\text { mengambil manfaat dari } \\
\text { sesuatu. (C2) }\end{array}$ \\
\hline & & $\begin{array}{l}\text { Diberikan teks } \\
\text { information report } \\
\text { tentang fenomena } \\
\text { alam (batuan), peserta } \\
\text { didik dapat } \\
\text { menemukan dasar } \\
\text { pengelompokan } \\
\text { batuan oleh ilmuwan } \\
\text { dengan benar. (C3) }\end{array}$ & $\begin{array}{l}\text { Diberikan teks } \\
\text { information report } \\
\text { tentang fenomena } \\
\text { alam (tanah), peserta } \\
\text { didik dapat } \\
\text { menemukan dasar } \\
\text { perbedaan pelapukan } \\
\text { oleh ilmuwan dengan } \\
\text { benar. (C3) }\end{array}$ & $\begin{array}{l}\text { Diberikan teks information } \\
\text { report tentang fenomena } \\
\text { sosial (uang), peserta didik } \\
\text { dapat menemukan } \\
\text { mekanisme ditemukannya } \\
\text { uang serta alasan } \\
\text { penggunaan bahan tertentu } \\
\text { untuk pembuatan uang } \\
\text { (C3) }\end{array}$ \\
\hline & & $\begin{array}{l}\text { Diberikan teks } \\
\text { information report } \\
\text { tentang fenomena } \\
\text { alam (batuan), peserta } \\
\text { didik dapat menyusun } \\
\text { outline/skema proses } \\
\text { pembentukan batuan } \\
\text { (C4) }\end{array}$ & $\begin{array}{l}\text { Diberikan teks } \\
\text { information report } \\
\text { tentang fenomena } \\
\text { alam (tanah), peserta } \\
\text { didik dapat membuat } \\
\text { rumusan subheading } \\
\text { dengan tepat (C4) }\end{array}$ & $\begin{array}{l}\text { Diberikan teks information } \\
\text { report tentang fenomena } \\
\text { sosial (uang), peserta didik } \\
\text { dapat membuat rumusan } \\
\text { subheading dengan tepat } \\
\text { (C4) }\end{array}$ \\
\hline & & $\begin{array}{l}\text { Diberikan teks } \\
\text { information report } \\
\text { tentang fenomena } \\
\text { alam (batuan), peserta } \\
\text { didik dapat } \\
\text { menyimpulkan alasan } \\
\text { penulis menyusun } \\
\text { paragraf terakhir. (C5) }\end{array}$ & $\begin{array}{l}\text { Diberikan teks } \\
\text { information report } \\
\text { tentang fenomena } \\
\text { alam (tanah), peserta } \\
\text { didik dapat } \\
\text { menyimpulkan alasan } \\
\text { penulis menyusun } \\
\text { paragraf terakhir. (C5) }\end{array}$ & $\begin{array}{l}\text { Diberikan teks information } \\
\text { report tentang fenomena } \\
\text { sosial (uang), peserta didik } \\
\text { dapat menyimpulkan } \\
\text { alasan penulis menyusun } \\
\text { paragraf awal dan terakhir } \\
\text { (C5) }\end{array}$ \\
\hline & & & $\begin{array}{l}\text { Diberikan teks } \\
\text { information report } \\
\text { tentang fenomena } \\
\text { alam (tanah), peserta } \\
\text { didik dapat menyusun } \\
\text { solusi untuk } \\
\text { melindungi tanah. } \\
\text { (C6) }\end{array}$ & $\begin{array}{l}\text { Diberikan teks information } \\
\text { report tentang fenomena } \\
\text { sosial (uang), peserta didik } \\
\text { dapat menyusun kembali } \\
\text { teks dengan jumlah kalimat } \\
\text { yang terbatas (dalam versi } \\
\text { ringkas). C6 }\end{array}$ \\
\hline
\end{tabular}


Catatan harian dan foto yang telah didokumentasikan dalam bentuk word digunakan untuk mendukung data primer dalam pembahasan hasil penelitian.

Secara kuantitatif keberhasilan penelitian ini diukur berdasarkan hasil tes dan angket. Berdasarkan hasil tes, penelitian ini berhasil apabila diperoleh kenaikan rerata perolehan skor minimal sebesar 20 secara klasikal dari Siklus 1 ke siklus-siklus berikutnya. Berdasarkan hasil angket, penelitian ini berhasil apabila terdapat kenaikan persentase rerata peserta didik yang menjawab "Yakin" dan "Sangat Yakin" pada pernyataan 4, 5, dan 6 minimal sebesar 5\%. Peningkatan secara kuantitatif ini menunjukkan peningkatan KBTT peserta didik ynag diukur dengan tes dan angket sebagai instumen pengkonfirmasi keyakinan peserta didik atas kemampuannya menjawab soal sesuai tipe.

\section{Hasil dan Pembahasan Hasil Tes}

Tes dilaksanakan sebanyak 3 (tiga) kali, yakni Tes Awal Pra Siklus yang berfungsi untuk memperoleh gambaran awal keterampilan berpikir peserta didik, Tes Akhir Siklus 1 dan Tes Akhir Siklus 2. Hasil rekapitulasi 3 (tes) tersebut ditunjukkan oleh Gambar 2 berikut.

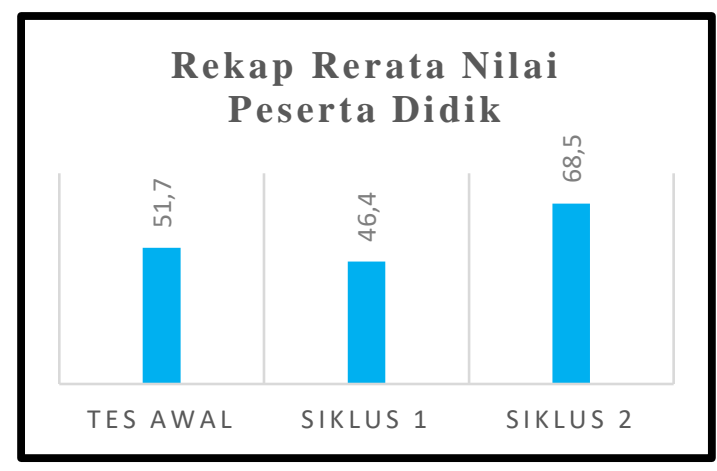

Gambar 2. Rekap Rerata Nilai Tes Awal, Siklus 1, Siklus 2

Perolehan rerata nilai Tes Akhir Siklus 1 sebesar 46,4. Perolehan ini justru mengalami penurunan sebesar 5,2 dibanding dengan rerata Tes Awal Pra Siklus. Sementara rerata Tes Akhir Siklus 2 yakni sebesar 68,5 ini mengalami kenaikan 20,1 dibanding dengan rerata hasil Tes Akhir Siklus 1. Kenaikan sebesar 22,1 dari Siklus 1 ke Siklus 2 ini sudah memenuhi indikator keberhasilan penelitian apabila ditinjau dari hasil tes.

Apabila dirunut proses pembelajaran pada Siklus 1, sebagian peserta didik menyampaikan masalah yang mereka hadapi pada saat refleksi akhir Siklus 1. Masalah mereka seputar kesulitan memahami teks, banyaknya kosa kata baru, kurangnya penjelasan awal, ketidaksiapan alat bantu berupa kamus, jarangnya menghadapi soal uraian sehingga peserta didik lebih menginginkan soal pilihan ganda. Dari pihak guru, pemberian feedback secara formatif untuk perbaikan pembelajaran juga belum berfungsi optimal. Brookhart (2010) menekankan pentingnya mengamati dan mendiskusikan proses penalaran peserta didik secara langsung, memberikan asesmen (tes) secara formatif beserta feedback yang substantif. Dengan memahami alur penalaran peserta didik, guru dapat menemukan ketidaksesuaian alur berpikir dalam memahami teks yang diberikan. Hasil koreksi pekerjaan peserta didik menunjukkan tidak optimalnya jawaban peserta didik untuk tipe soal C3, C4, C5, dan C6. Hal ini kemungkinan merupakan dampak kurang efektifnya pemberian feedback selama proses pembelajaran. Pada pelaksanaan Siklus 1, feedback terhadap jawaban sebagai hasil reasoning peserta didik lebih banyak disampaikan secara klasikal sehingga kurang berdampak bagi individu peserta didik. Oleh karena itu, penyampaian feedback pada siklus 2 dilaksanakan dalam kelompok kecil karena pembelajaran pada siklus 2 dilaksanakan dalam kelompok kecil yang dibentuk oleh guru.

Pelaksanaan tindakan Siklus 2 mengalami peningkatan dalam sejumlah hal sebagai tindak lanjut hasil refleksi. Pada Siklus 2 ini, peserta didik bekerja dalam kelompok yang dibentuk oleh guru berdasarkan kemampuan. Tiap kelompok memiliki komposisi kemampuan heterogen yang diharapkan dapat menumbuhkan semangat tutor sebaya. Selain perubahan komposisi anggota kelompok, peserta didik diizinkan menggunakan kamus, pemberian penjelasan awal tentang kosa kata baru, penyampaian feedbacck terhadap hasil reasoning dilakukan secara tertulis pada worksheet. Tindakan-tindakan sebagai langkah perbaikan ini berdampak positif terhadap meningkatnya rerata hasil tes di akhir Siklus 2, dari 46,5 menjadi 68,5. Blggs \& Collis (1982) dalam Brookhart (2010) menyatakan bahwa hirarki keterampilan berpikir terkait dengan berapa jumlah elemen dan berapa hubungan antarelemen. Semakin tinggi level berpikir semakin banyak elemen informasi yang terkait sehingga hubungan antarelemen tersebut juga semakin rumit dan kompleks. Pertanyaan pada FAR Worksheet didesain secara hirarkis dari level terendah sampai tertinggi. Demikian pula pertanyaan pada tes awal dan tes akhir pada setiap siklus. Apabila peserta didik menjawab secara urut, mereka akan mampu merasakan bahwa soal secara gradual memerlukan proses berpikir yang semakin kompleks dan rumit. Akibatnya, jawaban peserta didik semakin tidak 
optimal seiring semakin tingginya level berpikir yang dipersyaratkan.

\section{Hasil Angket}

Berdasarkan hasil angket, penelitian tindakan ini dikategorikan berhasil apabila terdapat kenaikan rerata persentase jumlah peserta didik yang menjawab "Yakin" dan "Sangat Yakin" pada pernyataan 4, 5, dan 6 sebesar 5\%. Tabel 4 di bawah ini menunjukkan adanya fluktuasi persentase jumlah peserta didik yang menjawab "Yakin" dan "Sangat Yakin". Persentase pada pernyataan 4 mengalami kenaikan 18,84\% menunjukkan kenaikan level berpikir dari applying ke analyzing. Pada pernyataan 5 , persentase mengalami penurunan. Pertanyaan C5 dengan level berpikir evaluating menuntut peserta didik mampu membuat judgment yang logis berdasarkan hasil analisis yang cermat. Melihat pola jawabannya, peserta didik terjebak pada kata-kata yang tersurat pada teks. Padahal membuat judgment seharusnya menggunakan kata-katanya sendiri. Persentase pada pernyataan 6 dengan level berpikir yang lebih tinggi justru mengalami peningkatan. Hal ini lebih disebabkan oleh output hasil membaca berupa skema atau bagan atau outline yang tidak menuntut kemampuan merumuskan kalimat dengan kata-kata sendiri.

Tabel 4. Hasil Anget Kategori "Yakin" dan "Sangat Yakin"

\begin{tabular}{lccccc}
\hline \multicolumn{1}{c}{ Pernyataan } & Siklus & Siklus & $\begin{array}{c}\% \\
\text { Siklus }\end{array}$ & $\begin{array}{c}\% \\
\text { Siklus }\end{array}$ & $\begin{array}{c}\% \\
\text { Kenaikan }\end{array}$ \\
& 1 & 2 & 1 & 2 & \\
\hline $\begin{array}{l}\text { Pernyataan 4 "Saya dapat menjawab pertanyaan } \\
\text { nomor 4 (C4)" }\end{array}$ & 8 & 12 & 33,33 & 52,17 & 18,84 \\
$\begin{array}{l}\text { Pernyataan 5 Saya dapat menjawab pertanyaan } \\
\text { nomor 5 (C5)" }\end{array}$ & 4 & 2 & 16,67 & 8,70 & $-7,97$ \\
$\begin{array}{l}\text { Pernyataan 6 Saya dapat menjawab pertanyaan } \\
\text { nomor 6 (C6)" }\end{array}$ & 5 & 7 & 20,83 & 30,43 & 9,60 \\
\hline Rerata & 5,67 & 7 & 23,61 & 30,43 & 6,82 \\
\hline
\end{tabular}

Tabel 4 di atas menunjukkan adanya kenaikan rerata persentase sebesar $6,82 \%$ sedikit melampaui indikator keberhasilan. Pernyataan 4, 5, dan 6 secara berurutan mengkonfirmasi kemampuan peserta didik dalam menjawab pertanyaan tipe C4, C5, dan C6 pada tes akhir siklus.

Tipe soal C4 menurut Brookhart (2010) mengukur keterampilan level analyzing yang dapat berupa pertanyaan yang berfokus pada pencarian gagasan pokok, menganalisis argumen, mengomparasikan dan mengontraskan. Tipe soal C5 mengukur keterampilan berpikir evaluating, dan pertanyaan C6 mengukur keterampilan berpikir creating. Baik pada Tes Akhir Siklus 1 maupun 2, pertanyaan tipe $\mathrm{C} 4$ ini berbunyi "Formulate the subheading". Merumuskan subheading merupakan salah satu cara mengemas pertanyaan untuk mencari gagasan pokok dan merumuskan gagasan tersebut dengan pernyataan yang mudah dipahami.

Tipe soal C5 mengukur bagaimana peserta didik melakukan penilaian terhadap sesuatu berdasarkan kriteria yang disepakati Pada Tes Akhir Siklus 1 pertanyaan tipe C5 berbunyi "What can you say about the last subheading?" Pada Tes Akhir Siklus 2 berbunyi "Why is it important for the writer to make the first paragraf and the last paragraf?" Kedua pertanyaan tersebut mengukur bagaimana peserta didik menilai beserta alasan penilaiannya yang masuk akal.

Tipe soal C6 mengukur apakah peserta didik dapat mengorganisasi ulang sesuatu yang telah ada menjadi sesuatu yang baru dalam hal misalnya menghasilkan solusi baru terhadap masalah yang sama atau merancang prosedur. Pada Tes Akhir Siklus 1 pertanyaan C6 nya berbunyi "The last paragraf says, "Because it takes so long for soil to form, people now understand that they must protect this important resource." Make some possible solutions how people protect the soil." Peserta didik diharapkan menghasilkan solusi sesuai konteks alam atau lingkungan terdekatnya. Sebagian peserta didik terjebak dengan memberikan jawaban sebagaimana yang ada di teks. Pada Tes Akhir Siklus 2 pertanyaan C6 nya berbunyi "Make a brief summary of the text, not more than 5 sentences." Pada tes ini peserta didik diminta menyusun kembali fakta-fakta yang ada di teks soal menjadi teks baru yang merupakan hasil analisis dan evaluasi sehingga dapat merangkum dengan kalimat ringkas dan efektif.

Kenaikan rerata peserta didik yang menyatakan keyakinannya terhadap kemampuan 
mereka menjawab pertanyaan level analyzing, evaluating, dan creating sudah memenuhi kriteria keberhasilan penelitian ini, meskipun masih sangat kecil. Upaya meningkatkan keterampilan berpikir tingkat tinggi memerlukan upaya terencana dan berkelanjutan.

\section{Hasil Pengamatan Proses Pembelajaran}

Hasil analisis data pengamatan proses pembelajaran tidak merupakan indikator keberhasilan yang utama dalam penelitian tindakan ini. Tujuan dilakukannya pengamatan ini untuk melihat seberapa baik kualitas proses pembelajaran yang diukur berdasarkan sejumlah objek yang diamati. Tabel 5 dan Tabel 6 berikut merangkum hasil pengamatan proses pembelajaran baik guru maupun peserta didik.

Tabel 5. Rangkuman Hasil Pengamatan Kegiatan Guru

\begin{tabular}{lcc}
\hline \multicolumn{1}{c}{ Objek yang Diamati } & $\begin{array}{c}\text { Siklus } \\
1\end{array}$ & $\begin{array}{c}\text { Siklus } \\
2\end{array}$ \\
\hline $\begin{array}{l}\text { Kejelasan guru dalam } \\
\text { memberikan penjelasan awal }\end{array}$ & 2,5 & 2,7 \\
$\begin{array}{l}\text { Keseriusan guru dalam } \\
\text { mengamati kegiatan berdiskusi }\end{array}$ & 2,9 & 3,0 \\
$\begin{array}{l}\text { Kecermatan guru dalam } \\
\text { memantau pekerjaan peserta } \\
\text { didik }\end{array}$ & 2,6 & 2,7 \\
$\begin{array}{l}\text { Keseriusan guru dalam memberi } \\
\text { feedback/reasoning }\end{array}$ & 2,9 & 3,0 \\
$\begin{array}{l}\text { Kejelasan guru dalam } \\
\text { menyampaikan kesimpulam }\end{array}$ & 2,8 & 3,0 \\
$\begin{array}{l}\text { Baiknya guru dalam menutup } \\
\text { pelajaran }\end{array}$ & 3,1 & 3,1 \\
$\begin{array}{l}\text { Keterlaksanaan pemberian tes } \\
\text { akhir, angket, dan diskusi } \\
\text { refleksi }\end{array}$ & 3,0 & 3,0 \\
\hline
\end{tabular}

Berdasarkan Tabel 5 di atas, dalam hal memberikan penjelasan awal guru sudah melakukannya dengan cukup baik meskipun masih perlu ditingkatkan lagi sampai benar-benar seluruh peserta didik dapat menerima penjelasan guru. Selama peserta didik berdiskusi, guru sudah menunjukkan keseriusannya dalam mengamati kegiatan diskusi. Dalam mengecek dan memantau pekerjaan peserta didik guru masih harus bekerja lebih keras lagi. Belum semua peserta didik mendapatkan layanan ini. Kecermatan guru dalam memberikan feedback menentukan langkah peserta didik berikutnya dalam memperbaiki pekerjaannya. Kecermatan mengecek dan keseriusan memberi feedback saling terkait. Dalam memberi feedback guru sudah menunjukkan sikap seriusnya. Hal ini ditunjukkan dengan menuliskan feedback langsung di lembar kerja peserta didik. Keterampilan guru dalam menarik kesimpulan sebelum menutup pembelajaran menentukan kuat tidaknya sebuah konsep bertahan di memori peserta didik. Dalam dua objek yang diamati ini guru sudah menunjukkan kemampuan baiknya. Keterlaksanaan tes akhir, angket dan refleksi sudah optimal di kedua siklus.

Tabel 6. Rangkuman Hasil Pengamatan Kegiatan Peserta Didik

\begin{tabular}{lcc}
\hline \multicolumn{1}{c}{ Objek yang Diamati } & $\begin{array}{c}\text { Siklus } \\
1\end{array}$ & $\begin{array}{c}\text { Siklus } \\
2\end{array}$ \\
\hline $\begin{array}{l}\text { Keseriusan peserta didik dalam } \\
\text { memperhatikan penjelasan awal } \\
\text { guru }\end{array}$ & 2,3 & 2,7 \\
$\begin{array}{l}\text { Keaktifan peserta didik dalam } \\
\text { kegiatan berdiskusi }\end{array}$ & 2,1 & 2,7 \\
$\begin{array}{l}\text { Keberanian mencoba peserta } \\
\text { didik dalam menuliskan }\end{array}$ & 1,8 & 2,6 \\
$\begin{array}{l}\text { rumusan jawaban peserta didik } \\
\text { Keseriusan peserta didik dalam } \\
\text { memperhatikan feedback/ } \\
\text { reasoning yang disampaikan } \\
\text { guru }\end{array}$ & 2,3 & 3,0 \\
$\begin{array}{l}\text { Keseriusan peserta didik dalam } \\
\text { mengikuti guru menyampaikan } \\
\text { kesimpulan }\end{array}$ & 2,0 & 2,9 \\
$\begin{array}{l}\text { Keikutsertaan peserta didik } \\
\text { dalam penyelesaian tes akhir, } \\
\text { angket, dan diskusi refleksi }\end{array}$ & 3,0 & 3,0 \\
\hline
\end{tabular}

Berbeda dengan hasil pengamatan kegiatan guru, berdasarkan Tabel 6, peserta didik masih menunjukkan kinerja kurangnya pada 5 objek yang diamati meskipun dengan tingkat keparahan yang berbeda. Objek teramati yang paling rendah terkait dengan keberanian mencoba dalam menuliskan rumusan jawaban. Hal ini terkonfirmasi dengan masukan peserta didik yang lebih menginginkan soal berbentuk pilihan ganda. Keberanian ini terbukti meningkat setelah pada Siklus 2 usulan untuk mengerjakan FAR Worksheet dengan berdiskusi kelompok diterima dan dilaksanakan. Keseriusan peserta didik dalam memperhatikan penjelasaan dan feedback guru juga masih dalam kategori rendah di Siklus 1.

Setelah mengetahui manfaat penjelasan awal dan feedback untuk perbaikan jawaban, peserta didik menunjukkan peningkatan keseriusannya dalam dua objek tersebut. Keaktifan dalam berdiskusi dan keseriusan dalam mengikuti penyampaian kesimpulan juga teramati meningkat. Secara keseluruhan, ditinjau dari peserta didik proses pembelajaran mengalami peningkatan menuju kategori "Tinggi". Merumuskan jawaban merupakan eksekusi terakhir dari proses berpikir. Semakin tinggi tipe pertanyaan, semakin kompleks dan rumit proses berpikir yang dipersyaratkan hingga mengerucut menjadi rumusan jawaban. 
Secara garis besar, berdasarkan data di atas hasil penelitian Shafeei, et al (2017) memperkuat hasil penelitian ini. Shafeei et. al (2017) menegaskan bahwa guru yang mengimplementasikan keterampilan berpikir tingkat tinggi (KBTT) dalam pembelajarannya menghadapi masalah terkait dengan sikap peserta didik terutama peserta didik dengan hasil belajar rendah. Peserta didik kelompok ini tidak hanya mengalami kesulitan dalam beradaptasi dengan perubahan baru, tetapi juga dalam hal merespon pertanyaan yang masih bersifat tekstual atau tersurat. Data dari penelitian Shafeei et.al (2017) ini menunjukkan bahwa ada 2 (dua) tipe peserta didik yang teramati, yakni 1) peserta didik yang cenderung menggunakan jawaban singkat, dan 2) peserta didik yang tidak memahami maksud pertanyaan yang disampaikan oleh guru. Berdasarkan masukan salah satu peserta didik di penelitian ini, pertanyaan supaya dibuat berbentuk pilihan ganda sehingga tidak perlu merumuskan sendiri jawabannya. Tipe peserta didik ini termasuk dalam tipe pertama di penelitian Shafeei et.al (2017).

Keberhasilan peningkatan kualitas proses pembelajaran baik dari kegiatan guru maupun peserta didik masih perlu terus diupayakan. Yoke et.al (2015) dalam hasil penelitian skala kecilnya menyatakan bahwa guru merasa percaya diri dan yakin dalam mengajarkan content tetapi masih belum siap apabila harus melibatkan KBTT dalam pembelajaran di kelas mereka. Malini dan Sarjit (2014) dalam Yoke et.al (2015) mengemukakan bahwa kesenjangan antara pengetahuan content pedagogis dan implementasi KBTT dalam pembelajaran bahasa lebih disebabkan oleh ketidakberdayaan guru melakukan inovasi untuk mengintegrasikan KBTT dalam pembelajarannya. Persiapan dan perencanaan merupakan hal vital. Disamping itu, sikap positif dan kreativitas dalam berinovasi juga memberikan kontribusi dalam keberhasilan pembelajaran.

\section{Simpulan dan Saran}

Berdasarkan hasil penelitian dan pembahasan dapat disimpulkan bahwa KBTT peserta didik kelas IXE pada semester 2 tahun pelajaran 2019/2020 meningkat melalui Formative Assessment with Reasoning (FAR) Worksheet. Keberhasilan ini dibuktikan dengan terpenuhinya indikator atau kriteria baik berdasarkan hasil tes akhir maupun hasil angket. Berdasarkan tes, nilai rerata Siklus 1 sebesar 46,4 dan Siklus 2 sebesar 68,5. Dengan demikian ada kenaikan sebesar 22,1 yang berarti telah memenuhi ketercapaian indikator keberhasilan, yakni 20. Berdasarkan angket, rerata persentase peserta didik yang menjawab "Yakin" dan "Sangat Yakin" pada pernyataan 4,5, dan 6 pada Siklus 1 sebesar 23,61 dan Siklus 2 sebesar 30,43. Dengan demikian, terdapat kenaikan sebesar $6,82 \%$, yang berarti telah memenuhi kriteria keberhasilan penelitian sebesar 5\%. Kualitas proses pembelajaran juga teramati meningkat berdasarkan hasil pengamatan baik kegiatan guru maupun peserta didik. Keberhasilan dalam memenuhi indikator atau kriteria berarti KBTT peserta didik meningkat meskipun dengan angka yang masih relatif rendah. Penggunaan FAR Worksheet yang diperkuat dengan pengelolaan kelas, pemilihan dan pengorganisasian materi, pemberian feedback, pemanfaatan kamus, dan kolaborasi antarpeserta didik dalam diskusi kelompok menunjukkan dampak positif terhadap peningkatan KBTT.

Sejumlah saran perlu disampaikan kepada para pemangku kepentingan dalam pembelajaran. Bagi guru, mengembangkan KBTT peserta didik seharusnya menjadi agenda pembelajaran semua mata pelajaran. Bagi peneliti, penelitain terkait pengembangan KBTT dapat dilakukan guru mata pelajaran apapun. Penelitian ini sebaiknya dilakukan secara berkesinambungan, mengalir sesuai rancangan pembelajaran yang sudah disusun. Dengan demikian, penelitian dapat berjalan seiring dengan proses pembelajaran. Dalam praktik pembelajaran di kelas, adalah ranah guru sebagai peneliti untuk secara berkesinambungan mengembangkan KBTT peserta didik. Bagi peserta didik, penguasaan KBTT merupakan modal survive pada abad ke-21. Peserta didik sebaiknya mulai mengubah pola pikir bahwa keberhasilan belajar tidak sekedar diukur dengan tingginya nilai yang diperoleh. Terkait dengan pembelajaran Bahasa Inggris, peserta didik disarankan untuk terus meningkatkan kemampuan membaca teks berbahasa Inggris. Kemampuan membaca (baca: literasi) seseorang menjadi salah satu softskill mutlak untuk hidup di era ini dan ke depan lagi. Sekolah sebagai lembaga pendidikan formal sebaiknya memberikan dukungan dan fasilitasi nyata dalam upaya pengembangan KBTT. Dukungan dan fasilitasi ini dapat berupa pemenuhan sarana prasarana yang memudahkan warga sekolah mengembangkan KBTTnya. Terkait dengan guru, sekolah hendaknya menyusun program yang berkesinambungan agar guru dapat terus melakukan penelitian atau paraktik baik dalam pembelajaran di kelasnya masing-masing, tentu dalam koridor peningkatan KBTT. 


\section{Daftar Pustaka}

. (2018). Permendikbud nomor 37 tahun 2018 tentang perubahan atas Permedikbud nomor 24 tahun 2016 tentang Kompetensi Inti dan Kompetensi Dasar Kurikulum 2013.

Anderson, Mark \& Kathy Anderson. (1997). Text Types in English. South Yarra: Macmillan Education Australia PTY Ltd.

Anderson, Lorin W. \& David R. Krathwohl. (2001). A Taxonomy for Learning, Teaching, and Assessing: A Revision of Bloom's Taxonomy of Educational Objectives. New York: Addison Wesley Longman, Inc.

Biech, Elaine. (2015). 101 Ways to Make Learning Active Beyond the Classroom. New Jersey: John Wiley \& Sons, Inc.

Brookhart, Susan M. (2010). How to Assess Higher-order Thinking Skills in Your Classroom. Virginia: ASCD Member Book.

Brown, H. Douglas. (2001). Teaching by Principles: An Interactive Approach to Language Pedagogy, $2^{\text {nd }}$ Edition. New York: Addison Wesley Longman, Inc.

Butterworth, John \& Geoff Thwaites. (2013). Thinking Skills: Critical Thinking and Problem Solving-2 $2^{\text {nd }}$ Edition. Cambridge: Cambridge University Press

Chapman, Carolyn \& Rita King. (2012). Differentiated Assessment Strategies-One Tool Doesn't Fit All $2^{\text {nd }}$ Ed. California: Corvin A SAGE Company.

Dubin, Fraida \& Elite Olshtain. (1994). Course Design. Cambridge: Cambridge University Press.
Kemmis, Stephen, Robbin Mc Taggart, Rhonda Nixon. (2014). The Action Research Planner: Doing Critical Participatory Action Research. London: Springer.

Shafeei, Khairon Nisa, Hanita Hasan, Fauziah Ismail \& Azian Abdul Aziz. (2017). Incorporating Higher Order Thinking Skills (HOTS) Questions in ESL Classroom Contexts. LSP International Journal, 4(1), 101-116.

Tim Direktorat Pembinaan SMP. (2017) Panduan Penilaian oleh Pendidik dan satuan Pendidikan untuk Sekolah Menengah Pertama. Jakarta: Direktorat PSMP Dirjen Dikdasmen Kemendikbud

Tohir, Mohammad. (2019). Hasil PISA Indonesia Tahun 2018 Turun Dibanding Tahun 2015. Tersedia Online: https://matematohir.wordpress.com/2019/ 12/03/hasil-pisa-indonesiatahun-2018turun-dibanding-tahun-2015/ Desember 2019]

Tomlinson, C.A. \& Tonya R. Moon. (2013). Assessment and Student Success in a Differentiated Classroom. Virginia: ASCD Publication.

Yoke, Soo Kum, Nor Haniza Hasan, Rohani Jangga \& Siti Nuur-Ila Mat Kamal. (2015). Innovating with HOTS for the ESL Reading Class. English Language Teaching, 8(8), 1017. 